J-SANAK: Jurnal Kajian Anak

(p-ISSN: 2686-5343 le-ISSN: 2715-7989)

Vol. (1) (2), (Januari-Juni) (2020), (Halaman)(35-46)

DOI: https://doi.org/10.24127/j-sanak.v1i02.201

\title{
PERAN MEDIA CORONG PADA PEMBELAJARAN MATEMATIKA MIN MA'ARIF BEGO
}

\author{
Namiroh Lubis \\ Universitas Islam Negeri Sunan Kalijaga \\ namirohlubis17@gmail.com
}

\begin{abstract}
ABSTRAK
Matematika adalah pembelajaran yang sulit bagi siswa. maka dengan adanya media corong yang digunakan akan membantu memudahkan guru dalam menyampaikan konten materi pembelajaran kepada siswa. Penelitian ini menggunakan metode penelitian kualitatif deskriptif dan sumber data dalam penelitian ini adalah kepala sekolah, guru dan siswa MIN Ma'arif Bego. Pengumpulan data dilakukan dengan cara mengamati dan melakukan wawancara pada guru kelas dan kepala sekolah. Setelah data terkumpul, akan dilakukan analisis data dengan menggunakan triangulasi data dari model Milles dan Hubberman. Hasil penelitian ini adalah dengan adanya guru yang kreatif dalam belajar sehingga siswa akan dengan mudah mempelajari materi pembelajaran. Selain itu, guru juga menggunakan buku kurikulum 2013 sebagai referensi dalam mengatur kegiatan belajar di kelas. Dalam kurikulum 2013 media dalam setiap kegiatan pembelajaran telah dipelajari. Media corong sebagai media yang dapat meningkatkan materi pembelajaran dan meningkatkan kognitif siswa.
\end{abstract}

Kata Kunci: Media Dan Perkalian

Received: 06-05-2020; Received in revised: 08-06-2020; Accepted 08-06-2020

\begin{abstract}
Mathematics is difficult learning for students. then the funnel media used will help facilitate the teacher in delivering the content of learning materials to students. This study uses descriptive qualitative research methods and data sources in this study are the principal, teachers and students of MIN Ma'arif Bego. Data collection is done by observing and conducting interviews with class teachers and school principals. After the data is collected, data analysis will be performed using data triangulation from the Milles and Hubberman models. The results of this study are the presence of teachers who are creative in learning so students will easily learn the learning material. In addition, teachers also use the 2013 curriculum book as a reference in managing learning activities in the classroom. In the 2013 curriculum the media in every learning activity was studied. Funnel media as media that can improve learning materials and improve students' cognitive.
\end{abstract}

Keywords: Media and Multiplication

Copyright (C) 2020, Universitas Muhammadiyah Metro| 35 
J-SANAK: Jurnal Kajian Anak

(p-ISSN: 2686-5343 le-ISSN: 2715-7989)

Vol. (1) (2), (Januari-Juni) (2020), (Halaman)(35-46)

DOI: https://doi.org/10.24127/j-sanak.v1i02.201

\section{A. PENDAHULUAN}

Proses pembelajaran yang tertuang dalam Peraturan Menteri Pendidikan dan Kebudayaan RI No. 65 Tahun 2013 mengarahkan pada pembelajaran yang interaktif, inspiratif, menyenangkan, menantang, memotivasi peserta didik untuk berpartisipasi aktif serta memberi ruang yang cukup bagi prakarsa, kreativitas, dan kemandirian sesuai bakat dan minat. (PERMENDIKBUD: No 65 Tahun 2015) Peraturan tersebut seirama dengan Peraturan Menteri Pendidikan dan Kebudayaan RI No. 22 Tahun 2006 yang menyatakan bahwa mata pelajaran matematika diberikan kepada seluruh peserta didik untuk membekali mereka dengan kemampuan berpikir logis, analitis, sistematis, kritis, dan kreatif, serta kemampuan bekerjasama. (PERMENDIKBUD: No 22 Tahun 2006)

M. Yusuf Setia Wardana dan Aries Tika Damayani menyatakan pada peraturan ini ditegaskan pula bahwa pembelajaran matematika di sekolah bertujuan agar peserta didik memiliki kemampuan memecahkan masalah yang meliputi keterampilan memahami masalah, merencanakan model matematika, penyelesaian model dan menjelaskan solusi yang diperoleh. Peningkatan keterampilan berpikir tingkat tinggi telah menjadi salah satu prioritas dalam pembelajaran matematika sekolah. (M. Yusuf Setia Wardana dan Aries Tika Damayani: 2017)

Peran pembelajar adalah menyediakan, menunjukkan, membimbing dan memotivasi pebelajar agar mereka dapat berinteraksi dengan berbagai sumber belajar yang ada. Sumber belajar dapat dibuat untuk dapat memberikan pemahaman yang baik terhadap peserta didik. Sumber belajar selain kita merancang, akan tetapi kita dapat memilih dan memanfaatkan sumber yang ada di sekitar lingkungan sekolah. (Marifah Hermin: 2015)

Media sebagai alat untuk membantu siswa dalam menguraikan dan memahami nilai-nilai tempat seperti satuan, puluhan, ratusan, dan seterusnya sehingga memudahkan siswa melakukan perkalian dan menghilangkan kemungkinan kesalahan yang terjadi akibat salah menjumlahkan. Dengan menggunakan media pembelajaran peserta didik dapat berinteraksi langsung atau mengalami langsung kejadiannya.

Dalam pembelajaran matematika peserta didik harus mampu berpikir kritis, seperti halnya dalam materi perkalian. Peserta didik harus dapat berperan aktif dalam pembelajaran, agar pembelajaran aktif maka guru memberikan dorongan 
J-SANAK: Jurnal Kajian Anak

(p-ISSN: 2686-5343 |e-ISSN: 2715-7989)

Vol. (1) (2), (Januari-Juni) (2020), (Halaman)(35-46)

DOI: https://doi.org/10.24127/j-sanak.v1i02.201

yang dapat mendorong siswa untuk lebih terampil dalam pembelajaran. Media merupakan salah satu pendorong dalam pembelajaran, dengan media yang menarik pembelajaran akan tercapai.

Menurut teori Edward L. Thordike mengemukakan bahwa matematika adalah sebagai teori stimulus-respon. Teori ini menyatakan bahwa pada hakikatnya belajar adalah proses pembentukan hubungan antara stimulus dan respon. Latihan yang sering kali dilakukan pada pembelajaran matematika pada dasarnya menggunakan hubungan antara stimulus dan respon akan memiliki hubungan yang kuat jika proses pengulangan yang memberikan dampak positif adalah pengulangan yang frekuensi nya teratur, bentuk pengulangan yang tidak membosankan, dan disajikan dengan cara menarik. (Erman Suhermawan: 2003)

Matematika sebagai pembelajaran yang dapat dilakukan dengan berulangulang dan menggunakan cara yang berbeda-beda. Selain itu, matematika juga sebagai pembelajaran yang memiliki pengaruh terhadap proses pembelajaran dan sikap siswa, yaitu dapat mengerjakan dengan sendiri sehingga menimbulkan sikap positif pada diri siswa. Matematika sebagai pembelajaran yang memiliki aturan tersendiri sehingga membutuhkan berbagai media sebagai alat dalam menyampaikan pembelajaran.

Matematika sebagai mata pelajaran yang memiliki teknik tersendiri dan menggunakan cara tersendiri dalam bentuk penyelesaian. Maka sebelum pembelajaran guru biasanya menyiapkan pedoman dalam pelaksanaan pembelajaran, yaitu RPP (rencana pelaksanaan pembelajaran). RPP yang disiapkan guru sebagai bahan dalam pembelajaran terdiri dari komponenkomponen, yaitu kompetensi dasar, indikator, tujuan, metode, media atau alat peraga, materi, langkah-langkah pembelajaran dan evaluasi pembelajaran.

Pembelajaran dengan Menggunakan media dalam proses belajar mengajar memiliki dua peranan penting, yaitu : 1) Media sebagai alat bantu mengajar atau disebut sebagai dependent media karena posisi disini sebagai alat bantu (efektivitas), dan 2) Media sebagai sumber belajar yang digunakan sendiri oleh peserta didik secara mandiri atau disebut dengan dependent media. (Nasution S: 2005)

Media corong adalah alat peraga yang tergolong sederhana dengan mudah untuk dibuat sebagai alat bantu dalam pembelajaran matematika. Media corong digunakan secara konkret dalam pembelajaran agar mudah untuk dipahami. Tujuan dari media corong, yaitu untuk lebih mudah memahami konsep 
J-SANAK: Jurnal Kajian Anak

(p-ISSN: 2686-5343 |e-ISSN: 2715-7989)

Vol. (1) (2), (Januari-Juni) (2020), (Halaman)(35-46)

DOI: https://doi.org/10.24127/j-sanak.v1i02.201

penjumlahan bilangan, memahami konsep penjumlahan dan mampu menghitung operasional perkalian dengan penjumlahan berulang. (Sundayana Rostina: 2013)

Peran guru dalam pembelajaran sangat penting, untuk itu guru hendaknya menciptakan pembelajaran yang menarik dan dapat menumbuhkan minat siswa dalam belajar sehingga siswa akan mudah dalam memahami materi yang disampaikan. Salah satu cara yang dapat digunakan oleh guru yaitu dengan menggunakan media. Media dalam pembelajaran matematika terutama untuk materi operasi hitung sudah digunakan oleh disebagian sekolah yang dinamakan media corong perkalian. Akan tetapi, media ini masih ada kekurangannya yaitu media hanya digunakan pada materi perkalian, media terbuat dari kardus sehingga sehingga tidak tahan lama.

Penelitian tentang pembelajaran matematika sejauh ini membahsa tentang model yang dapat meningkatkan keberhasilan, seperti penelitian Winda Maharani. Hasil dari penelitian tersebut menjelaskan bahwa melalui media pembelajaran, hasil dan ketercapaian akademik meningkat. (Winda Maharani: 2017) Dalam penelitian ini akan menjelaskan bahwa media dalam pembelajaran matematika bukan tentang hasil ketercapaian dari peserta didik. akan tetapi, peserta didik mudah memahami isi materi dengan media pembelajaran yang sudah dijelaskan dalam setia buku pedoman guru yaitu kurikulum 2013.

Permasalahan dalam penelitian adalah masing kurangnya guru memahami isi buku kurikulum 2013. Dalam kurikulum 2013 sudah dijelaskan media yang digunakan dalam setiap mata pelajaran. Hal ini dilaksanakan agar dapat memudahkan guru dalam melaksanakan kegiatan belajar mengajar. Sesuai dengan permasalahan di atas penulis ingin mengetahui bagaimana peran media corong dalam pembelajaran matematika?.

Media atau alat peraga memiliki peran dalam proses pembelajaran Matematika agar tujuan pembelajaran tercapai. Dalam hal ini peneliti menggunakan sebuah alat peraga dalam proses pembelajaran matematika yakni dengan menggunakan alat peraga Corong berhitung dengan menggunakan alat peraga corong perkalian.

\section{B. MOTODOLOGI}

Penelitian ini menggunakan penelitian kualitatif deskriptif. Data dihimpun dengan pengamatan yang seksama, mencakup deskripsi dalam konteks yang mendetail disertai catatan-catatan hasil wawancara yang mendalam, serta hasil analisis dokumen dan catatan-catatan. (Nana Syaodih Sukmadinata: 2012) 
J-SANAK: Jurnal Kajian Anak

(p-ISSN: 2686-5343 le-ISSN: 2715-7989)

Vol. (1) (2), (Januari-Juni) (2020), (Halaman)(35-46)

DOI: https://doi.org/10.24127/j-sanak.v1i02.201

Penelitain ini menggunakan pendekatan kualitatif yang dimulai dari tahap pengumpulan data secara alamiah (apa adanya, dalam situasi normal yang tidak dimanipulasi keadaan dan kondisinya), dengan teknik observasi langsung ke lokasi peneliti, selanjutnya melakuakan wawancara yang mendalam terhadap responden yang diharapkan dapat dan layak sebagai informasi, mengadakan teknik pengumpulan data dengan observasi, wawancara dan dokumentasi. (Sugiono: 2012)

Sumber data dalam penelitian ini adalah kepala sekolah, guru dan peserta didik MIN Ma'arif Bego. Guru kelas dan peserta didik sebagai objek utama dalam penelitian karena interaksi pembelajaran tercapai berdasarkan guru dan peserta didik. Sedangkan kepala sekolah sebagai subjek penguat dalam penelitian ini. Teknik pengumpulan data dalam penelitian yakni dengan melakukan wawancara dengan guru kelas dan mengobservasi kegiatan pembelajaran. Analisis data menggunakan model Milles dan Hubberman dalam sugiono, yaitu dengan reduksi data, penyajian data, dan verification. (Sugiono: 2012)

\section{HASIL PEMBAHASAN}

Pelaksanaan pembelajaran dalam kurikulum 2013 telah disusun dengan baik, yaitu dengan adanya buku guru dan buku siswa. Dengan adanya buku guru, pendidik lebih mudah melaksanakan kegiatan belajar mengajar. Buku guru sudah membuat media yang digunakan dalam kegiatan pembelajaran, hal ini bertujuan untuk memudahkan peserta didik memahami materi.

Sebagaimana teori yang ditelah dikemukakan oleh Edward L. Thordike bahwa matematika adalah sebagai teori stimulus-respon. Maka pembelajaran matematika sebagai suatu proses belajar mengajar yang dibangun oleh guru untuk mengembangkan kreativitas berfikir siswa yang dapat meningkatkan kemampuan berfikir siswa, serta dapat mengkontruksi pengetahuan baru sebagai upaya meningkatkan penguasa yang baik terhadap materi matematika

Pelaksanaan kegiatan pembelajaran belajar mengajar yang dilaksanakan guru di MI sudah lebih baik khususnya dalam setiap mata pelajaran. Penggunaan buku dalam kegiatan belajar mengajar sebagai pendukung dalam mengembangkan pola pikir peserta didik. Buku panduan yang digunakan guru adalah buku kurikulum 2013. Buku kurikulum 2013 sudah memuat media pembelajaran yang digunakan dalam setiap mata pelajaran. Dalam buku guru mengajarkan guru untuk lebih kreatif dalam mengembangkan setiap materi. Maka sebelum guru memulai kegiatan belajar mengajar harus memahami konsep dari setiap mata pelajaran. 
J-SANAK: Jurnal Kajian Anak

(p-ISSN: 2686-5343 |e-ISSN: 2715-7989)

Vol. (1) (2), (Januari-Juni) (2020), (Halaman)(35-46)

DOI: https://doi.org/10.24127/j-sanak.v1i02.201

Matematika sebagai mata pembelajaran yang sangat sulit menurut siswa. Hal ini sesuai hasil wawancara dengan guru kelas II buku panduan yang sudah disediakan dalam kegiatan pembelajaran sudah lebih baik. Tetapi guru terkadang tidak menggunakan sebuah media dalam pembelajaran karena masih kurang menguasai dalam setiap konsep mata pembelajaran.

Dari hasil wawancara maka sebelum dimulai kegiatan belajar mengajar harus memahami konsep dalam kegiatan pembelajaran. Hal ini sesuai dengan teori Edward L. Thordike bahwa dalam pembelajaran matematika itu harus ada stimulus respon.

\section{Konsep Pembelajaran Matematika}

Materi pembelajaran adalah segala sesuatu yang dibahas dalam pembelajaran dalam rangka mencapai tujuan yang telah ditetapkan. Jadi, yang dimaksud dengan pembelajaran matematika adalah serangkaian kegiatan belajar siswa dalam pelajaran matematika untuk mencapai tujuan yang telah ditetapkan. Tujuan umum pembelajaran matematika di SD yaitu agar siswa terampil dalam menggunakan berbagai konsep matematika. Tujuan khusus pembelajaran matematika di SD yaitu agar siswa memahami dan menggunakan sifat-sifat operasi hitung khususnya operasi hitung perkalian dua angka dengan dua angka yang merupakan kompetensi dasar yang baru bagi siswa kelas II sehingga kemampuan dasar melakukan operasi hitung perkalian dikuasai oleh siswa.

Seiring masuknya anak pada jenjang SD/MI, kemampuan kognitifnya turut mengalami perkembangan yang pesat. Dengan masuk sekolah, berarti dunia dan minat anak bertambah luas. Dengan meluasnya minat maka bertambah pula pengertian tentang manusia dan objek-objek yang sebelumnya.

Pembelajaran matematika adalah proses pembelajaran yang menemukan banyak pengalaman, berusaha mencari temuan baru, dan dapat mengembangkan kreativitas sehingga dapat meningkatkan kognitif peserta didik. Dengan demikian, pembelajaran matematika dapat memberikan peluang baru kepada siswa untuk meningkatkan keterampilan serta pengetahuan yang lebih baik.

Salah satu karakteristik matematika adalah objek kajiannya abstrak. Oleh karena itu untuk mempelajari matematika diperlukan cara khusus yang tidak sama dengan mempelajari mata pelajaran lain. Berikut ini dipaparkan tentang bagaimana seharusnya belajar matematika.

Matematika sebagai kegiatan pembelajaran mental yang tinggi, karena matematika berkaitan dengan ide-ide abstrak yang diberi simbol-simbol yang 
J-SANAK: Jurnal Kajian Anak

(p-ISSN: 2686-5343 le-ISSN: 2715-7989)

Vol. (1) (2), (Januari-Juni) (2020), (Halaman)(35-46)

DOI: https://doi.org/10.24127/j-sanak.v1i02.201

tersusun secara hirarkis dan penalarannya deduktif. Untuk mempelajari matematika haruslah bertahap, berurutan serta mendasarkan pada pengalaman belajar yang lalu. Proses belajar matematika akan terjadi dengan lancar bila dilakukan secara kontinu. Sejalan dengan itu Soedjadi, menyatakan bahwa untuk dapat menguasai matematika diperlukan cara belajar yang berurutan, setapak demi setapak dan berkesinambungan.

Pada prinsipnya, perkalian sama dengan penjumlahan secara berulang. Oleh karena itu, kemampuan persyaratan yang harus dimiliki siswa sebelum mempelajari perkalian adalah penguasaan penjumlahan. Lambang perkalian adalah ' $x$ '. Defenisi perkalian adalah jumlah berganda dengan suku-suku yang sama, misalnya $2+2+2+2+2$. Disebut jumlah berulang. Disini terdapat lima suku yang sama yaitu 2. Penjumlahan ini disajikan pula dalam bentuk : 5 x 2 dan disebut perkalian 5 dan 2. (Yayuk Dwiastuti: 2012)

Kunci dari belajar matematika adalah dengan memahami materi penambahan, pengurangan, perkalian dan pembagian. Materi yang wajib dikuasai siswa adalah perkalian. Materi tersebut materi esensial yang cukup lama proses penanamannya. Bahkan, kalau sudah disajikan dalam soal cerita seringkali siswa mengalami kesulitan. Oleh karena itu, berbagai upaya untuk meningkatkan mutu pelajaran khususnya mata pelajaran matematika terus dilakukan. Upaya itu antara lain dengan penggunaan media yang tepat. Disamping itu, faktor lain yang mempengaruhi hasil belajar adalah dari dalam diri siswa maupun dari luar siswa.

Berdasarkan wawancara dengan guru kelas II pembelajaran matematika itu adalah pembelajaran yang menyenangkan dengan berbagai media atau cara guru dalam menyampaikan. Karakteristik pembelajaran ini abstrak sehingga siswa tidak mengalaminya secara langsung, namun dengan berbagai pembelajaran yang menyenangkan guru mengajarkan dengan menggunakan berbagai cara dalam mengembangkan ilmu pengetahuan menjadi lebih berpengalaman seperti dengan menggunakan teknik atau strategi dalam pembelajaran.

Strategi yang dapat memberikan pembelajaran lebih menyenangkan dengan menggunakan media yang sederhana. Dengan adanya media, peserta didik akan lebih mengalami kejadian yang mereka pelajari. Corong sebagai media yang digunakan mereka sering menjumpainya, namun hanya dipakai untuk bermain biasa. Setelah peserta didik mulai pembelajaran maka peserta didik lebih memanfaatkan benda yang dapat mereka buat untuk pembelajaran.

Oleh karena itu guru sekurang-kurangnya dapat menggunakan alat atau media pembelajaran yang sesuai dengan materi serta memiliki pengetahuan dan 
J-SANAK: Jurnal Kajian Anak

(p-ISSN: 2686-5343 le-ISSN: 2715-7989)

Vol. (1) (2), (Januari-Juni) (2020), (Halaman)(35-46)

DOI: https://doi.org/10.24127/j-sanak.v1i02.201

pemahaman yang cukup tentang media pembelajaran. Mengingat media merupakan bagian yang penting dan tidak dapat terpisahkan dari proses belajar mengajar demi tercapainya tujuan pendidikan pada umumnya dan tujuan pembelajaran di sekolah pada khususnya.

Siswa pada umumnya hanya menghafal informasi yang diperoleh, sehingga konsep yang tertanam kurang begitu kuat. Selain itu, banyak siswa yang hasil belajarnya rendah bahkan ada yang sangat rendah, terutama pada pelajaran matematika dalam hal hitung-menghitung. Di sini siswa kurang mampu, bahkan ada juga yang tidak mampu dalam memahami cara Perkalian dengan benar. Ini semua disebabkan karena tidak adanya media pembelajaran yang relevan untuk digunakan dalam menyampaikan materi pembelajaran kepada siswa dan keterbatasan guru dalam menyampaikan materi pelajaran.

Berdasarkan teori Piaget bahwa pada awalnya anak belajar melalui hal-hal yang konkrit. Untuk memahami konsep matematika yang bersifat abstrak, anak memerlukan benda-benda konkrit atau real sebagai visualisasinya. Selain Piaget, beberapa ahli lain menggemukakan pandangannya tentang perkembangan belajar seseorang adalah Dienes dan Bruner. (Ibrahim dan Suparni: 2008)

Pembelajaran matematika terdapat dua objek yang diperoleh, yaitu objek langsung dan tidak langsung. Objek tidak langsung berupa kemampuan menyelidiki dan memecahkan masalah, belajar mandiri, sikap positif terhadap matematika, dan tahu bagaimana mestinya belajar. Objek langsung berupa fakta, keterampilan, konsep dan aturan matematika.

\section{Media Corong}

Media pembelajaran adalah segala sesuatu yang dapat digunakan untuk menyalurkan pesan dari pengirim ke penerima sehingga merangsang pikiran, perasaan, perhatian dan minat serta kemampuan peserta didik sedemikian rupa sehingga proses belajar terjadi dalam rangka mencapai tujuan pembelajaran secara efektif. Media pembelajaran diasumsikan sebagai alat komunikasi pembelajaran. Dalam proses komunikasi pembelajaran terdapat komponen-komponen didalamnya, yaitu sumber pesan, pesan, penerima pesan, media dan umpan balik.

Sesuai dengan teori menurut Edward L. Thordike harus ada sitmulus respon dalam pembelajaran matematika. Pembelajaran matematika dengan stimulus respon akan lebih mudah dipahami. Berdasarkan hasil obeservasi ketika guru menggunakan media corong peserta didik lebih antusias dalam mengikuti 
J-SANAK: Jurnal Kajian Anak

(p-ISSN: 2686-5343 |e-ISSN: 2715-7989)

Vol. (1) (2), (Januari-Juni) (2020), (Halaman)(35-46)

DOI: https://doi.org/10.24127/j-sanak.v1i02.201

kegiatan belajar mengajar. Hal ini karena ada dorongan dan motivasi dalam kegiatan belajar mengajar.

Wali kelas II mengatakan menggunakan media pembelajaran yang dapat mencapai tujuan pembelajaran dengan berdasarkan pengalaman yang dimiliki oleh peserta didik. Apalagi dalam posisinya mereka masih senang bemain, maka guru menggunakan media yang sering digunakan peserta didik dalam bermain. Dalam bermain siswa sering menjumpai pembelajaran yang mereka pelajari termasuk dalam perkalian.

Pembelajaran menggunakan media pembelajaran corong hitung juga dapat mengoptimalkan belajar sehingga hasil belajar siswa meningkat. Alat peraga dapat digunakan untuk menyampaikan suatu isi pelajaran, memperjelas dan menarik perhatian siswa sehingga dapat mendorong proses pembelajaran yang pada akhirnya dapat meningkatakan hasil belajar, dengan digunakannya alat peraga pesan yang disampaikan menjadi lebih jelas dan mudah diterima siswa.

Dalam proses pembelajaran, pengembangan materi atau bahan ajar dapat melalui berbagai cara, salah satunya adalah pengembangan bahan ajar dengan optimalisasi media. Media yang digunakan untuk memperlancar komunikasi dalam proses pembelajaran sering diistilahkan media pembelajaran. Salah satu media yang digunakan dalam pembelajaran dan diyakini dapat lebih menggairahkan animo siswa dalam proses pembelajaran di kelas adalah media Audio Visual.

Alat peraga Corong perkalian adalah salah satu media pembelajaran yang digunakan untuk mengenal perkalian sebagai penjumlahan berulang dengan menggunakan corong dan biji-bijian yang akan ditujukan kepada siswa-siswi sekolah dasar sehingga dapat meningkatkan hasil belajar matematika. Corong berhitung dibuat dari barang-barang bekas, seperti kardus, kertas karton warna, tali, biji-bijian/manik-manik dan lain-lain. (Munawarah, Usman Mulbar, Ilham Minggi: 2013)

Sesuai standar isi Matematika, tujuan utama pembelajaran Matematika adalah untuk mengembangkan potensi peserta didik. Diharapkan peserta didik akan terbentuk sikap peka terhadap masalah yang terjadi di masyarakat, memiliki sikap mental positif terhadap perbaikan segala ketimpangan yang terjadi, dan terampil mengatasi setiap masalah yang menimpa dirinya sendiri maupun yang menimpa masyarakat.

Sebagai implikasi dari hakikat belajar matematika itu maka proses pembelajaran matematika merupakan pembentukan lingkungan belajar yang dapat 
J-SANAK: Jurnal Kajian Anak

(p-ISSN: 2686-5343 |e-ISSN: 2715-7989)

Vol. (1) (2), (Januari-Juni) (2020), (Halaman)(35-46)

DOI: https://doi.org/10.24127/j-sanak.v1i02.201

membantu siswa untuk mebangun konsep-konsep atau prisip-prinsip matematika berdasarkan kemampuannya sendiri melalui proses internalisasi.

Salah satu kesulitan utama dalam mengajarkan perkalian adalah memahami konsep suatu himpunan sebagai satu entitas dan pada saat yang sama, entitas tersebut juga merupakan kumpulan dari beberapa benda atau objek. Anak-anak bisa menyelesaikan soal, Berapa banyak apel yang ada dalam 4 kerajang jika masing-masing keranjang berisi apel 8 apel? Dengan menghitung 4 himpunan pencacah yang masing-masing berisi 8 pencacah, kemudian menghitung jumlah pencacah tersebut secara keseluruhan. Untuk bisa berpikir secara multiplikatif mengenai soal ini yaitu empat himpunan dari 8, anak-ank harus bisa mengkonseptualisasikan setiap kelompok delapan tersebut sebagai satu benda saja. (John A. Van De Walle: 2008)

Berdasarkan kutipan diatas, salah satu pengembangan dalam pembelajaran memberikan konsep, memberikan contoh yang siswa mudah untuk memahaminya, dan umpan balik yang dapat mendorong siswa untuk mengerjakan soal. Hal tersebut dilakukan guru untuk memberikan dorongan pada siswa untuk lebih giat dalam belajar.

Untuk mengetahui peran dari media pembelajaran memerlukan sumber dari guru dan siswa. Maka berdasarkan hasil observasi sementara guru masih menggunakan media yang berdasarkan diketahuinya saja belum mencoba media yang ada pada buku tematik atau dengan menggunakan media corong tersebut. Media yang lakukan guru dengan menggunakan permen atau kerikil terkadang belum efektif. Maka dari itu guru perlu menggunakan media corong dalam pembelajaran.

Penggunaan media corong dalam perkalian akan efektif apabila siswa dibagi berdasarkan kelompok yang telah ditetapkan oleh guru berdasarkan Rencana Pelaksanaan Pembelajarannya. Upaya yang di harapkan guru dalam media adalah untuk membantu menggefektifkan pembelejaran. Perkalian adalah hal yang mendasar bagi siswa maka agar pembelajaran itu dapat tersamapaikan guru harus mencari jalan agar siswa lebih cepat paham.

Sasaran dari observasi ini adalah media corong dapat membantu siswa dalam pemahaman perkalian, agar siswa merasa nyaman dalam proses pembelajaran. Banyak sekali manfaat dari media pembelajaran. Sangat jelas sekali perbedaan hasil belajar dari penjelasan lisan saja dibandingkan disertai dengan menggunakan media pembelajaran yang relevan yaitu dengan media pembelajaran benda konkret. Media pembelajaran benda konkret ini terbukti sangat mudah dipelajari. 
J-SANAK: Jurnal Kajian Anak

(p-ISSN: 2686-5343 le-ISSN: 2715-7989)

Vol. (1) (2), (Januari-Juni) (2020), (Halaman)(35-46)

DOI: https://doi.org/10.24127/j-sanak.v1i02.201

\section{KESIMPULAN}

Peran media corong dapat digunakan untuk menanamkan konsep perkalian. Media corong ini juga dapat menabah keterampilan siswa dengan menggunkan alat yang sederhana. Hasil penilitian dan pengembangan yang telah dilakukan menunjukkan bahwa produk media corong berhitung dapat membantu guru dalam menjelaskan konsep perkalian dan pembagian. Selain itu, dengan adanya media corong berhitung pada materi perkalian dan pembagian, dapat mempermudah siswa dalam melakukan perkalian dan pembagian. Dengan demikian, media corong berhitung dapat menunjang proses pembelajaran matematika di Sekolah Dasar.

Perlunya inovasi dalam pembelajaran matematika, khusunya untuk tingkat $\mathrm{SD} / \mathrm{MI}$ agar pembelajaran yang dilakukan sesuai dengan tahapan psikologis dan kognitif siswa. Salah satu sifat anak adalah suka dengan keterampilan maka dari itu hal yang paling konkret yang dapat mendorong minat belajaran siswa dengan menggunkana media corong perkalian.

Media pembelajaran corong hitung memberikan pengaruh yang positif pada siswa sehingga guru dapat menerapkannya sebagai salah satu alternatif media pembelajaran yang digunakan untuk penjumlahan, pengurangan dan pembagian. Guru hendaknya menggunakan media pembelajaran yang tepat agar tercipta suasana belajar yang aktif, menyenangkan dan efektif sehingga diharapkan hasil belajar siswa dapat meningkat.

\section{E. DAFTAR PUSTAKA}

Dewi Lestari, Penerapan Teori Bruner untuk Meningkatkan Hasi Beljar Siswa pada Pembelajaran Simetri Lipat di Kelas IV SDN 02 Makmur Jaya Kabupaten Mетијu Utara, Jurnal Kreatif Todulako Online Vol. 3 No. 2, ISSN 2354-614X, 2010.

Dwiastuti Yayuk, Penerapan Model Pembelajaran Make A Match Untuk Meningkatkan Kemampuan Menjumlah Berbagai Macam Bentuk Pecahan Pada Siswa Kelas V SD, Jurnal Inspirasi Pendidikan Universitas Kanjuruhan Malang,

Hamzah Ali dan Muhlisrarini, Perencanaan dan Strategi Pembelajaran Matematika, Jakarta: Rajawali, 2014.

Hermin Marifah, Meningkatkan Hasil Belajar Operasi Hitung Perkalian Bersusun Ke Bawah Dengan Media Papan Napier Pada Pembelajaran Matematika 
J-SANAK: Jurnal Kajian Anak

(p-ISSN: 2686-5343 le-ISSN: 2715-7989)

Vol. (1) (2), (Januari-Juni) (2020), (Halaman)(35-46)

DOI: https://doi.org/10.24127/j-sanak.v1i02.201

Bagi Siswa Kelas III SD Dapuan Surabaya, Jurnal Elemen Vol. 1 No. 1, Januari 2015.

Ibrahim dan Suparni, Strategi Pembelajaran Matematika, Yogyakarta: Bidang Akademik, 2008.

John A. Van De Walle, Matematika Sekolah Dasar Dan Menegah Pengembangan Matematika, Erlangga, 2008

Kustandi Cecep dan Sutjipto Bambang, Media Pembelajaran Manual dan Digital, Bogor: Ghalia Indonesia, 2011.

Munawarah, Usman Mulbar, Ilham Minggi, Desain Pembelajaran Matematika Realistik Di Kelas V Sd (Studi Pada SD Inpres 6/75 Kading) Jurnal Matematika Dan Pembelajaran (Mapan), Vol. 1 No. 1 Desember 2013: 92109.

Peraturan Menteri Pendidikan dan Kebudayaan RI No. 22 Tahun 2006 tentang Satndar Isi untuk Satuan Pendidikan Dasar dan Menengah.

Peraturan Menteri Pendidikan dan Kebudayaan RI No. 65 Tahun 2013 tentang Standar Proses Pendidikan Dasar dan Menengah.

Rostina, Sundayana, Media Pembelajaran Matematika, Bandung: IKAPI, 2013.

Sugiono, Metode Penelitian Pendidikan, Bandung: Alfabeta, 2012.

Suhermawan , Erman, dkk, Strategi Pembelajaran Matematika Kontemporer, (Bandung: Universitas Pendidikan Indonesia, 2003.

Sukiman, pengembangan media pembelajaran, yogyakarta: pustaka insan madani, 2012.

Sukmadinata Syaodih Nana, Metode Penelitian Pendidikan, Bandung: PT Remaja Rosdakarya, 2012.

Sulistiani Ratih Ika, Pembelajaran Matematika Materi Perkalian Dengan Menggunakan Media Benda Konkret (Manik -Manik Dan Sedotan) Untuk Meningkatkan Hasil Belajar Siswa Kelas 2 Sd Dinoyo 1 Malang, Jurnal Ilmiah Vicratina, Volume 10, No. 2 Nopember 2016,

Sulistyowati, Endang, Penggunaan Permainan Dalam Pembelajaran Perkalian di Kelas II SD/MI, Al-Bidayah: jurnal pendidikan dasar islam, volume 6, nomor 1, Juni 2014. ISSN: 2085-0034,

Susanto, Ahmad, Teori Belajar dan Pembelajaran di Sekolah Dasar, Jakarta: Prenada Media, 2013.

Wardana Setia Yusuf. M dan Damayani Tika Aries, Persepsi Siswa Terhadap Pembelajaran Pecahan Di Sekolah Dasar, Jurnal "Mosharafa", Volume 6, Nomor 3, September 2017, p-ISSN: 2086-4280; e-ISSN: 2527-8827. 